\title{
Winter regime of temperature and precipitation as a factor of snow-cover distribution and its stratigraphy
}

\author{
Vladimir N. GOLUBEV, Marina N. PETRUSHINA, Denis M. FROLOV \\ Faculty of Geography, Moscow State University, Leninskie Gory 1, MSU, 119992 Moscow, Russia \\ E-mail: golubev@geol.msu.ru
}

\begin{abstract}
The investigation of spatial and temporal variability of the snow cover in northern Eurasia (snow depth, density, thermal characteristics, water equivalent) includes large-scale fieldwork, modelling and analysis of meteorological data of two winters (2004/05 and 2005/06) from 38 weather stations situated in different climatic conditions and physico-geographical zones. Common regularities and features of snow-cover variability are revealed for these winters, despite their contrasting temperature and precipitation regimes and differences from an average winter, as the time of appearance, duration and depth of snow cover, the number of snowfalls and date of melting. The modelling of snow-cover stratigraphy is based on viscous compression and recrystallization laws. Meteorological information (temperature, wind velocity and precipitation) is used as input for the model. The output is the specific snow-cover stratigraphy according to positioning in different physicalgeographical regions and due to the possible variation as determined by winter temperature and precipitation regimes. The peculiarity of snow-cover stratigraphy at the regional scale depends on the meteorological conditions of its formation as well as on the character of landscapes. A satisfactory correlation of the modelled typical columns of the snow cover formed in 2004/05 and 2005/06 in different regions of Russia and of real columns is revealed.
\end{abstract}

\section{INTRODUCTION}

The observations at weather stations, specific snow courses and satellite imagery in the visual spectrum are the main sources of information about snow-cover distribution. The stratigraphic columns based on the data of the snow course and stationary observations reflect the features of snow accumulation and metamorphism and make it possible to evaluate snow water equivalent under specific landscape conditions. The structure, properties (thermal, density, permeability, etc.) and water storage of the snowpack in each of the plots can differ essentially from the corresponding characteristics in other localizations and from those typical for the region (Kolomyts, 1976; Golubev, 1987; Golubev and others, 2006). In such cases it is necessary to transform the real stratigraphy into an average profile which must include general features of snow-cover structure in proportions corresponding to the regime of snow accumulation and intensity of post-sedimentary processes in the entire region (Sturm and others, 1995).

Microwave survey of an area made in several bands (usually 19 and $37 \mathrm{GHz}$ ) can also give an estimate of the snow-cover water storage (Jogsberger and Mognard, 2002). The absorption of microwave radiation by snow and of the underlying surface depends on a wavenumber and is registered as a difference in brightness temperature within the cells about $1000 \mathrm{~km}^{2}$ in size. The difference is related to the snow-cover thickness, but the estimated ratios allow evaluation of the thickness or snow water equivalent of snow only in flat woodless areas with a dry snow cover which is homogeneous in terms of texture. Where there are ice layers, horizons of depth hoar, or damp snow inside the snowpack, and under conditions of afforested terrain, correction factors have to be applied to the calculation procedure. The value of the correction factors depends on the vegetation type, distribution and density of timber stand, as well as on the moisture content of snow, and on the relative frequency of texture heterogeneities (Derksen and LeDrew, 2000). Lack of direct data on snow-cover stratigraphy and its integral and differential density does not allow a reliable interpretation of remote-sensing data concerning the measurements of thickness and water storage of the snow cover, and, in some cases, even its presence or absence.

The possibility of modelling typical stratigraphic columns of the snowpack for different physical-geographical regions on the basis of a complex of factors determining the formation of snow-cover stratigraphy and its subsequent changes is analyzed in this paper.

\section{BASIC RELATIONS}

The snow-cover stratigraphy and its characteristics, such as wind, radiation and ice crusts, layers of depth hoar, differential and integral density, are formed under the influence of recurrent meteorological phenomena (e.g. snowfalls and thaws).

The processing of a standard set of weather observations (atmospheric pressure, temperature, precipitation, wind velocity, thickness of snow cover) included the choice of meteorological phenomena of a certain duration and intensity which can be regarded as factors in the formation of the snow-cover stratigraphy and texture features. Such factors are snowfalls, wind, thaws and temperature gradients within the snow cover. Temperature gradients within a snowpack were evaluated on the basis of region-averaged values of air and ground-surface temperatures. Wind forcing and air-temperature rise were considered as factors determining the formation of heterogeneous elements, such as crusts, within a snowpack. It was supposed that a wind velocity of about $10 \mathrm{~m} \mathrm{~s}^{-1}$ or a temperature increase up to daily average values exceeding $0^{\circ} \mathrm{C}$ results in formation of wind and ice crusts on the surface of deposited snow. In cases of subsequent snowfalls with an intensity of 
$>0.01 \mathrm{~g} \mathrm{~cm}^{-2} \mathrm{~d}^{-1}$ these crusts will divide neighbouring horizons of the snowpack. Less intensive snowfalls were not taken into consideration because a layer of fresh snow with water storage of $0.01 \mathrm{~g} \mathrm{~cm}^{-2}$ evaporates within $<24$ hours (Golubev and others, 2001). The number of snowfalls within the period of snow accumulation was estimated based on the assumption that two or several consequent periods of snowfall with the intensity of $>0.01 \mathrm{~g} \mathrm{~cm}^{-2}$ form one horizon of snow accumulation if: (1) the interval between periods of snowfalls was $<2$ or 3 days; (2) there was no rise in temperature up to $0^{\circ} \mathrm{C}$ and more during this interval; and (3) the average wind velocity was not $>10 \mathrm{~m} \mathrm{~s}^{-1}$. The changes of the horizon thickness with snow water equivalent corresponding to the amount of precipitation were estimated using the equation of viscous compaction during the time interval after each period of precipitation (Golubev and Guseva, 1987; Kominami and others, 1998). If the wind speed exceeded about $10 \mathrm{~m} \mathrm{~s}^{-1}$, the formation of a wind crust with a thickness up to $5 \mathrm{~mm}$ and an additional compaction of the surface snow layer were taken into consideration, which can constitute up to $10 \%$ of its initial density.

The formation of secondary foliation elements, such as ice crusts or soft horizons, can occur inside layers or at their boundaries and is connected to the thermal regime of the region. Horizons of depth hoar are formed at high temperature gradients in a snowpack $\left(>0.2 \mathrm{~K} \mathrm{~cm}^{-1}\right)$. At temperatures of $-7^{\circ} \mathrm{C}$ to $-12^{\circ} \mathrm{C}$ the intensity of mass exchange in a snowpack can reach $10^{-2} \mathrm{~g} \mathrm{~cm}^{-2} \mathrm{~d}^{-1}$, and 6-30 days are enough to form a layer of depth hoar (Kolomyts, 1976; Fierz, 1998). During short periods of temperature increase up to $0^{\circ} \mathrm{C}$ or higher the melting process begins in the upper layer of the snow cover, and an ice crust is formed on its surface. The melting intensity can be evaluated on the basis of the ratio according to which a snow layer corresponding to $0.3 \mathrm{~g}$ of meltwater can melt within 24 hours at an average air temperature of $1^{\circ} \mathrm{C}$ (Krenke and others, 2000). Freezing of this moisture in the underlying snow layer results in the formation of $1-5 \mathrm{~cm}$ of porous ice crust, which has a density of $400-600 \mathrm{~kg} \mathrm{~m}^{-3}$. During a long thaw, which can heat the whole snowpack up to $0^{\circ} \mathrm{C}$, meltwater infiltrates into the ground, and the volume of this flow is determined by the heat capacity and water-retaining capacity of the snow mass (Bader and Weilenmann, 1992; Kominami and others, 1998).

Modelling of the regional stratigraphy of the snowpack is based on standard information from network weather stations and the forecast of melting, compaction and recrystallization processes inside the snowpack; it includes several successive stages:

1. sequential layering of snow horizons, the thickness of which is set on the basis of data from weather stations, and the density of which is calculated from a water equivalent of precipitation fallen during a snowfall;

2. calculation of thickness change of the latest deposited horizon due to evaporation (Golubev and others, 2001, 2006);

3. calculation of thickness change of the latest deposited horizon when a wind crust is formed on its surface; the density of this crust is increasing relative to that of fresh snow for $10 \%$ every 24 hours under the influence of wind with a velocity exceeding $10 \mathrm{~m} \mathrm{~s}^{-1}$ (Dyunin, 1963; Golubev and others, 2006);
4. calculation of thickness change of the latest deposited horizon or several horizons when some part of fresh snow is melting during a thaw, taking into consideration: (a) formation of an ice crust at $20-30 \mathrm{~cm}$ depth or on the boundary with the underlying horizon, as well as density increase of the underlying snow as a result of a redistribution of melt moisture inside the snow according to moisture-retaining capacity; (b) flow of meltwater into the underlying ground if the thaw is intense (Bader and Weilenmann, 1992; Kominami and others, 1998);

5. calculation of each horizon thickness as a result of compaction taking into account the chronology of deforming force changes (Golubev and Guseva, 1987; Guseva and Golubev, 1989; Lehning and others, 1999);

6. calculation of thickness of a depth-hoar horizon using the gradient of water-vapour concentration in snow pore space (Guseva and Golubev, 1989; Fierz, 1998).

\section{RESULTS AND DISCUSSION}

Long-term changes of climatic conditions are accompanied by year-to-year variability of temperature and precipitation depending on a periodic change in the prevailing type of atmospheric circulation processes (quasi-biannual cyclic recurrence) (Fallot and others, 1997; Popova and Krenke, 2004); this variability often exceeds the value of trend changes during 10-15 years. In the second half of the 20th century, the increasing temperature trend of the cold period in northern Eurasia due to climatic changes was $0.032^{\circ} \mathrm{Ca}^{-1}$ while the amount of winter precipitation increased on average by $0.8 \mathrm{~mm} \mathrm{a}^{-1}$ (Razuvaev and others, 1995). The mean values of year-to-year variability during this period were $1.5^{\circ} \mathrm{C}$ for temperature and $10 \mathrm{~mm}$ for precipitation, and maximum values of the anomalies were $3^{\circ} \mathrm{C}$ and $30 \mathrm{~mm}$, respectively. The trend and year-to-year temperature and precipitation variability determine correspondingly the distribution and structure of the snow cover (thickness, peculiarities of stratigraphy, intraseasonal distribution, duration, water storage, etc.). The increase of temperature and precipitation amounts in the second half of the 20th century led to an increase of snow-cover thickness by $0.12 \mathrm{~cm} \mathrm{a}^{-1}$ (Krenke and others, 2000) while the average year-to-year thickness variability was $2 \mathrm{~cm}$, and the maximum value of anomalies was $7 \mathrm{~cm}$. The ratios between values of temperature, precipitation amount and snowcover thickness are close by the order of values and this allows year-to-year anomalies to be considered as an analogue of a possible snow-cover reaction to the existent and future climatic changes.

Analysis of changes in spatial and temporal distribution of snow cover in northern Eurasia during the 2004/05 and 2005/06 winter periods and modelling of typical stratigraphy columns of snowpack in different physical-geographical regions were carried out on the basis of standard meteorological information from 38 network weather stations. Data on real stratigraphy of snowpacks in different regions were used to verify the modelled columns.

During the winter periods (November-March) of 2004/05 and 2005/06, the deviations of average temperature and precipitation values as well as thickness and distribution of snow cover in northern Eurasia from average long-term values for the period 1961-90 were within the limits of standard variability. 

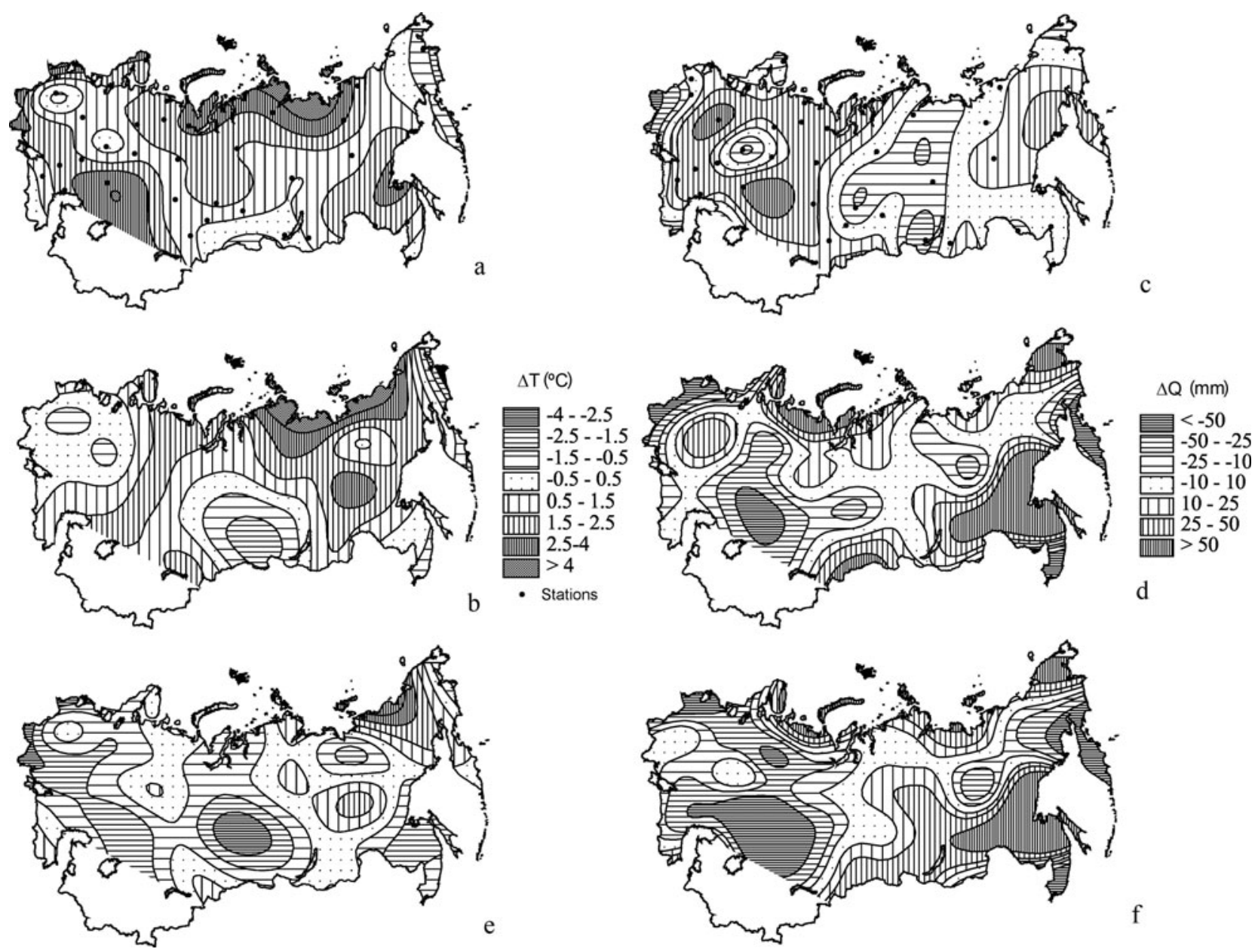

Fig. 1. $(a, b)$ Anomalies of average winter temperature, (c, d) amount of winter precipitation and (e, f) their interannual distinction (spline interpolation of the data from the stations).

Figure 1 shows anomalies of the average winter temperatures (Fig. 1a and b), the amount of winter precipitation (Fig. 1c and d) and the difference between the winter periods under consideration in terms of the temperature and precipitation regimes (Fig. 1e and f). Most of northern Eurasia was characterized by positive temperature anomalies during the 2004/05 and 2005/06 winter periods compared with the mean long-term values, while the highest anomalies were observed on the Arctic Ocean coast. Areas where no deviations were recorded in these years, or a decrease in the temperature was registered, are situated in the East European Plain, in western and central Siberia and in the Far East; they alternate with vast areas of warming, so it is possible to speak of a certain stability of longitude sectors, within each of which the trends of climatic conditions changes are opposite.

In the winter of 2004/05 the positive anomalies of the mean winter temperature in the sectors of warming did not exceed $1.5-2.0^{\circ} \mathrm{C}$ on average, increasing up to $4-8^{\circ} \mathrm{C}$ only in the north of eastern Siberia. In the sectors of temperature decrease, the negative anomalies were about $1^{\circ} \mathrm{C}$, but decreased to $2{ }^{\circ} \mathrm{C}$ on the eastern coast of the Kamchatka and Chukchi peninsulas. In winter 2005/06, areas of temperature increase and decrease were in the same regions. However, areas with negative anomalies increased several-fold, the temperature decrease in comparison with the average longterm value was $1.5-2.0^{\circ} \mathrm{C}$, and in central Siberia and in the Far East it reached $-2.5^{\circ} \mathrm{C}$. The zones where warming tendencies remained were reduced by nearly half in size, and the average value of positive anomalies decreased to $1.0-1.5^{\circ} \mathrm{C}$. The area of maximum positive anomalies was in the north of eastern Siberia as before, but its extent and the anomalies also decreased.

During these winter periods the positive anomalies of the precipitation amount were related to the sectors of warming (European Russia and eastern Siberia), while the negative anomalies were related to the sectors where temperature decreased (the western part of northern Eurasia, central Siberia, Primorye and the Far East). In 2004/05, maximum values of positive anomalies (up to $60 \mathrm{~mm}$ ) were recorded in the East European Plain and in the northern part of European Russia as well as in the southern Urals and eastern Siberia and on the coast of the Sea of Okhotsk; the decrease of the winter precipitation amount in 'cold' sectors did not exceed 30-40 mm. In 2005/06 the average decrease of the winter precipitation amount by $30-60 \mathrm{~mm}$ was recorded in almost the whole territory of northern Eurasia. Positive anomalies were observed only on the coast of the Arctic Ocean and in the piedmont surrounding the mountains of southern Siberia.

In characterizing year-to-year changes of average winter temperature and precipitation values, it should be noted that the whole winter of 2005/06 was colder and less snowy than the winter of 2004/05. Year-to-year changes were also of a sectoral character: the temperature decreased by $0.5-4.0^{\circ} \mathrm{C}$ in European Russia as well as in western and central Siberia, Primorye and the Far East, while the amount of winter precipitation decreased by $25-100 \mathrm{~mm}$. The areas of some 

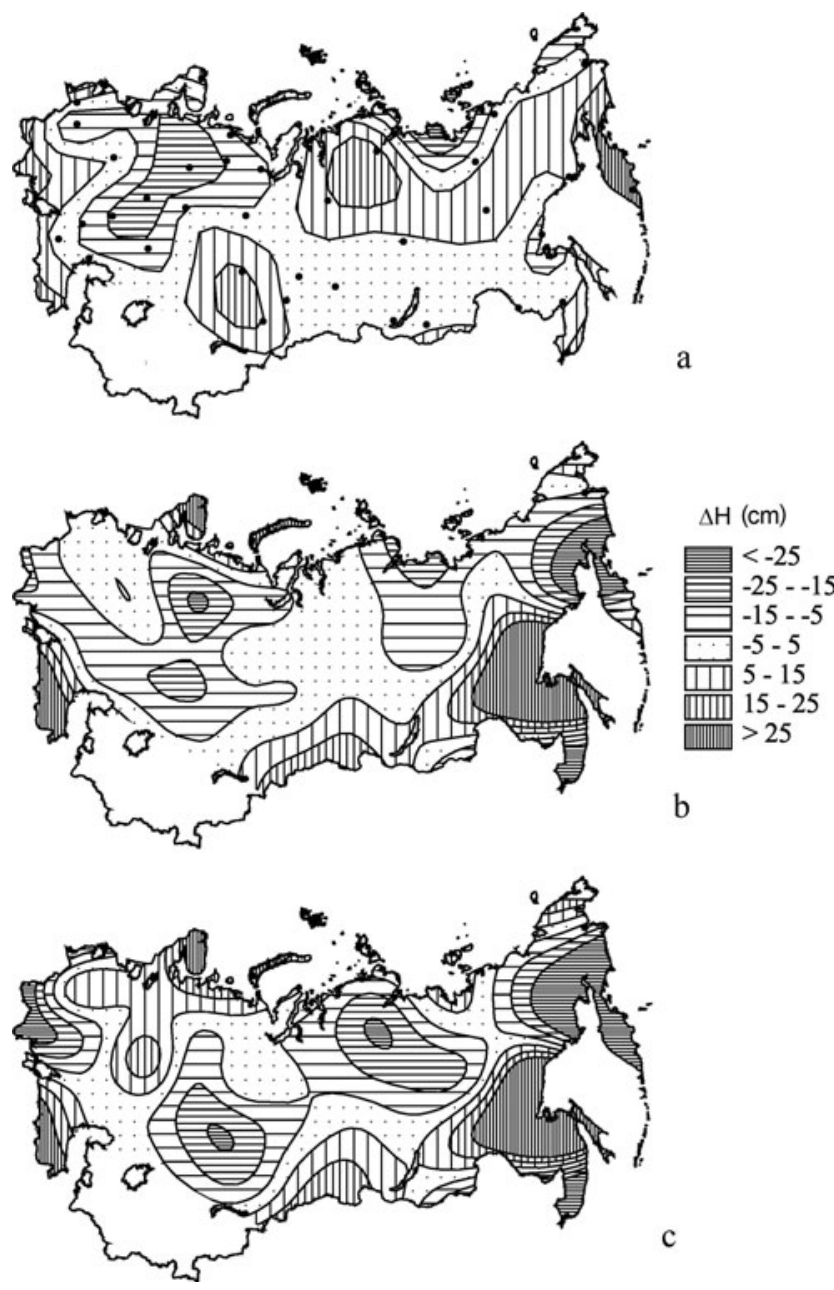

Fig. 2. Anomalies of snow-cover thickness in comparison with the average long-term values in (a) 2004/05 and (b) 2005/06, and (c) their interannual distinction.

rise in temperature and the winter precipitation amount lie on the coast of the Arctic Ocean and in the piedmont of the southern parts of Siberia and the Far East.

The anomalies of snow-cover thickness compared with the average long-term values and year-to-year changes in the analyzed years are shown in Figure 2. The increase of snowcover thickness by $10-30 \mathrm{~cm}$ by the end of the 2004/05 and 2005/06 winter periods was recorded in the middle latitudes of northern Eurasia from the Sea of Okhotsk to the Baltic Sea, with some maxima in the sectors of the East European Plain, western and eastern Siberia. The zones where the snowcover thickness decreased by $10-20 \mathrm{~cm}$ were situated in the sectors of central Siberia and the Baikal region, and in the northern part of the Far East, from the coast of the Arctic Ocean to the Sea of Okhotsk. In 2005/06 the areas of the zones where the snow-cover thickness decreased were more than twice those observed the previous winter. The distribution of the sectors with positive and negative snowthickness anomalies and especially a decrease of thickness in the northeastern part of Eurasia, where the most significant warming was recorded, shows that the changes of the snow-cover thickness depend not only on the amount of precipitation but also on temperature. The snow compaction rate grows exponentially with temperature rise (Golubev and Guseva, 1987; Kominami and others, 1998) and, in particular, this is the cause of the decrease of the snow-cover thickness by $10-30 \mathrm{~cm}$ in the eastern part of the Arctic Ocean coast, in spite of the precipitation increase by 30$50 \mathrm{~mm}$ while the average winter temperature increases by $2.5-4.0^{\circ} \mathrm{C}$.

The snow-cover stratigraphy develops in the process of snow accumulation and can be characterized by such parameters as the number of snowfalls leading to the formation of horizons, the total duration of periods with precipitation, and the average intensity of snowfalls measured in water equivalent of fresh snow.

Figure 3 shows the number and intensity of snowfalls in 2004/05 and 2005/06 and the year-to-year difference. The maximum quantity (up to 24 ) and intensity (up to $30 \mathrm{~mm}$ ) of snowfalls were observed in the zones of intensive cyclonic activity (regions of Kamchatka and the Far East, the northern part of the East European Plain and the southern part of western and central Siberia). In the zones of steady atmospheric processes (regions of central and northeastern Siberia) the number and intensity of snowfalls decreased by half. The number of snowfalls important for stratigraphy can both increase and decrease with year-to-year changes of temperature and precipitation amount; as a result, it is difficult to establish a certain correlation between the number of snowfalls and changes in winter precipitation amount. Thus, in the zone where the amount of precipitation decreased by $20-50 \mathrm{~mm}$, the number of snowfalls decreased from 16-18 to 10-12 in western Siberia, whereas in the Ural region the number increased from $12-14$ to 20 . Nevertheless, it is highly probable that within the zones where temperature and amount of winter precipitation decrease from year to year, snowfalls become less intensive, though the number can increase.

The formation of heterogeneous texture elements inside the snow cover, such as crusts of different genesis and loosesnow horizons, is associated with the processes developing inside the snow cover during the post-sedimentation period. The most essential transformation of the snowpack with the emergence of secondary foliation is caused by a diffusive mass exchange at a significant $\left(10-20^{\circ} \mathrm{C}\right)$ temperature drop within the snowpack or during recurrent thaws accompanied by the melting of surface snow layers.

If the temperature gradient within the snow cover is $20 \mathrm{~K} \mathrm{~m}^{-1}$ or more, an intensive recrystallization of snow and the formation of depth-hoar horizons occur; during a microwave survey this phenomenon is recorded as difference increase in brightness temperature and correlates with thicker snow cover. During the winter periods analyzed, both the amount of precipitation and the snow-cover thickness decreased (by up to $50 \mathrm{~mm}$ and by $10-50 \mathrm{~cm}$, respectively) in a part of northern Eurasia in spite of a rise in temperature (by $0.5-2.5^{\circ} \mathrm{C}$ ) in relation to the average longterm values. The most obvious were year-to-year changes. The winter of 2005/06 in almost the whole of Russian Eurasia, excluding the Arctic Ocean coast and the mountain surrounding Siberia from the south, was characterized by a simultaneous fall in temperature, amount of precipitation and snow-cover thickness as compared with winter 2004/ 05; this led to intensive recrystallization of snow, and resulted in overestimation of snow-cover thickness during the microwave survey.

Areas with an increased number of thaws are usually related to the belt of cyclonic vortex movements and can encompass several sectors. There is a somewhat unexpected regularity in the distribution of thaws: in most cases, thaws 

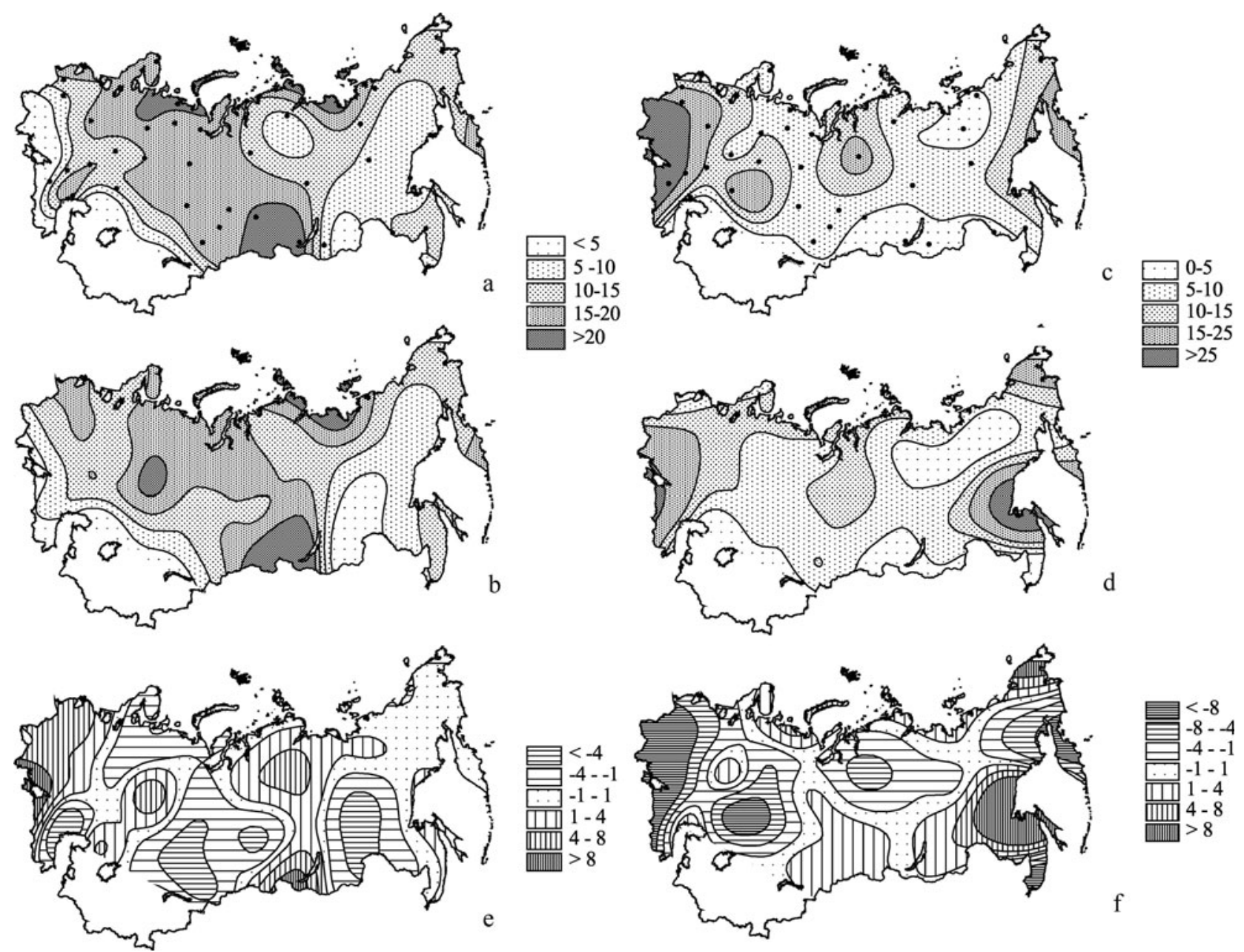

Fig. 3. Number and intensity of snowfalls in (a, b) 2004/05 and (c, d) 2005/06, and (e, f) their interannual distinction.

in the 'cold' sectors occur 1.5-4.0 times more often and are more intensive than in the 'warm' sectors (Fig. 4). Thus in the winters of 2004/05 and 2005/06 the thaws occurred more often (up to 8-10 times during the winter period) and were more intensive ( $\geq 5$ degree-days) in the western and southern regions of the East European Plain, in the south of western and central Siberia, as well as in the Far East and Kamchatka. Under conditions of year-to-year falls in temperature and precipitation, the amount and intensity of thaws increases in 'warm' sectors and decreases in 'cold' sectors, resulting in a more homogeneous distribution of thaws.

The possible amount of ice crusts within the snowpack and the degree of its regelation transformation can be characterized by such parameters as the ratio between the amount of thaws and the amount of snowfalls as well as the ratio between the total amount of meltwater (in $\mathrm{mm} \mathrm{cm}^{-2}$ ) emerging during thaws and the amount of precipitation (Fig. 5). The amount of meltwater emerging during thaws is estimated on the basis of regularities of snow-cover heat exchange with the atmosphere according to the number of degree-days of positive temperature. If the amount of meltwater exceeded $20 \%$ of precipitation and the number of thaws was more than or equal to the number of snowfalls, the snow cover underwent an intensive infiltration recrystallization even to the point of formation of an infiltration layer on the surface of the underlying ground and the flow of a part of meltwater into the ground. Where the meltwater portion was $<20 \%$, but the amount of meltwater exceeded the water-retaining capacity of snow equal to $12 \%$, and the ratio between the number of thaws and the number of snowfalls ranged from 1.0 to 0.3 , most snow-cover horizons were represented by coarse- or middle-grained freezing snow with ice layers usually on horizon boundaries. If the ratio between the number of thaws and the number of snowfalls is $0.3-0.1$ and the meltwater portion ranges from 0.05 to 0.12 , the snow cover can contain porous ice crusts, the number of which should correspond to the number of thaws. If the ratio between the number of thaws and the number of snowfalls is less than 0.1 and the meltwater portion is $<0.05$, the snow cover is made up of horizons of grained snow with rare regelation crusts.

Wind crusts are exceptions among heterogeneous texture elements of the snow cover as they are formed during or soon after sedimentation as a result of snow compaction due to drifting. A large number of wind crusts and the compaction of snow cover up to $300-400 \mathrm{~kg} \mathrm{~m}^{-3}$ are typical of vast open spaces in tundra or steppe zones. In other landscape zones wind crusts do not influence significantly the thermal properties and the integral density of the snow cover. At the same time, changes in thermal properties at the boundaries of wind crusts contribute to the formation of loose-snow horizons inside the snow cover and thus can play a determining role in the processes of emergence of avalanche hazards on mountain slopes.

The modelled typical columns of the snow cover formed in 2004/05 and 2005/06 in different regions of Russia (Fig. 6), 

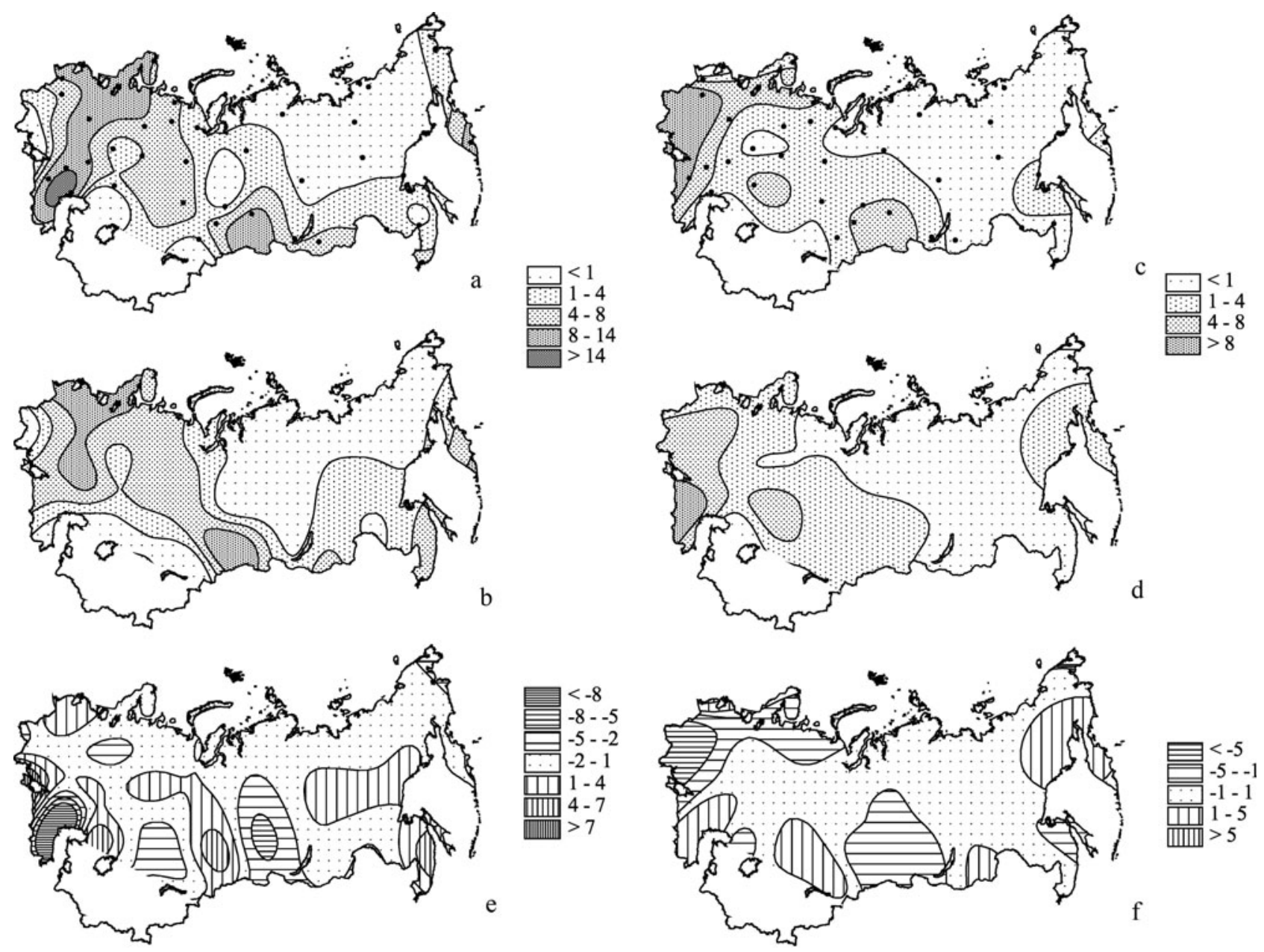

Fig. 4. Number and intensity of thaws in (a, b) 2004/05 and (c, d) 2005/06, and (e, f) their interannual distinction.
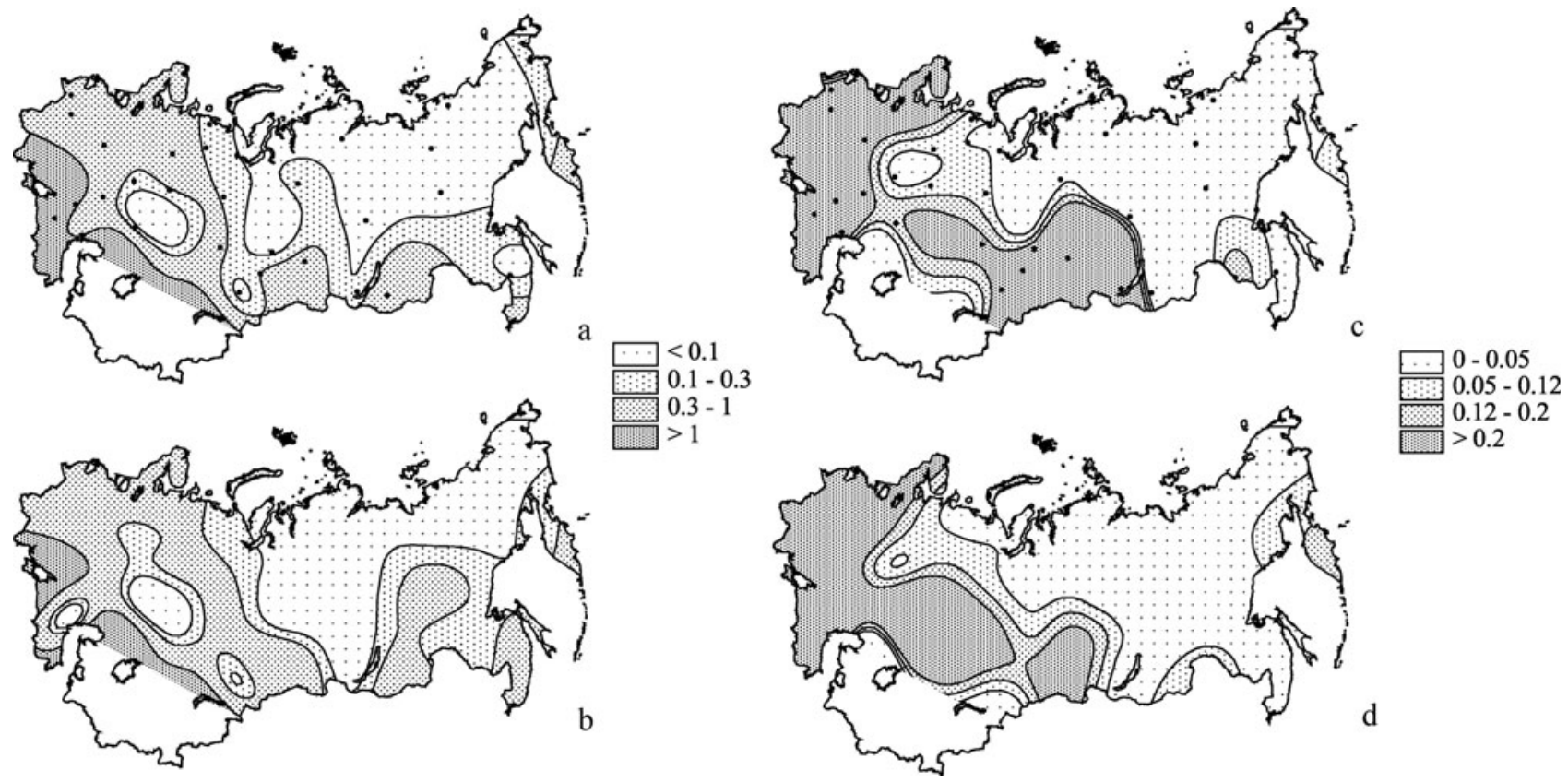

Fig. 5. (a, b) The ratio of the number of thaws to the number of snowfalls. (c, d) The ratio of the total amount of meltwater (in mm $\mathrm{cm}^{-2}$ ) emerging during thaws to the total amount of precipitation. 


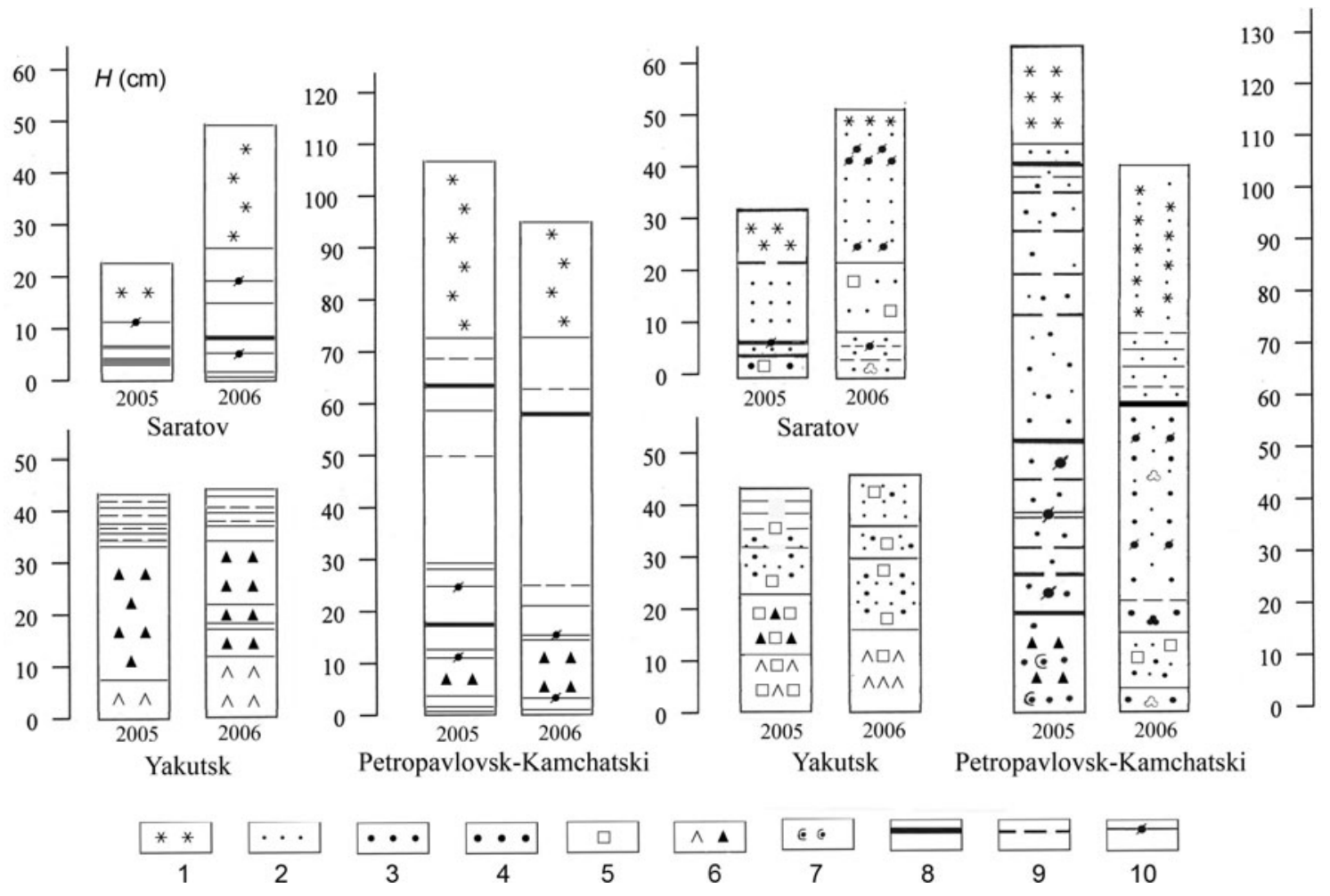

Fig. 6. The modelled typical columns of the snow cover formed in 2004/05 and 2005/06 in different regions of Russia: 1 . new snow; 2 . finegrained snow; 3. medium-grained snow; 4. coarse-grained snow; 5 . faceted crystals; 6 . hollow and solid crystals of depth hoar; 7 . refrozen ice crystals; 8 . ice crust; 9 . sun crust; 10 . wind crust.

although schematic, show regional differences in snowpack thickness and stratigraphy as well as its significant year-toyear distinction in each region. Field research in several regions (Saratov, Yakutsk and Petropavlovsk-Kamchatski) showed a satisfactory correlation between modelled and real columns of the snowpack. Naturally, the modelled columns reflect only a complex of meteorological conditions and do not take into consideration the impact of landscape structure at meso- and micro-levels. As for geosystems of a lower hierarchical scale, the characteristics of underlying ground, such as texture, temperature and moisture of soils, aspects of slopes, their steepness, relief forms and vegetation type, are of vital importance for spatial differentiation of snow structure, while the climatic component is mainly a background. That is why variations are possible in terms of the thickness of certain horizons, the number of ice and wind crusts, etc., while the principal characteristics of the snowpack stratigraphy remain the same. For example, in the Moscow region the largest snow accumulation occurred in forests on clearings, cuttings and edges, where the snowcover thickness reached $75-80 \mathrm{~cm}$ by mid-March. At the same time, in open space (near weather stations) it reached $55-58 \mathrm{~cm}$, in pine forests $36-42 \mathrm{~cm}$, and in fir forests it was minimal $(28-30 \mathrm{~cm})$ (Lokoshenko, 2005; Golubev and others, 2006).

\section{CONCLUSIONS}

Long-term changes in winter climatic conditions in northern Eurasia for the last 20 years were characterized by an increase in temperature, precipitation and snow-cover thickness. The distribution of climatic anomalies in the 2004/05 and 2005/06 winter periods is represented by sectors with opposite changes (a warming up and cooling off relative to the average long-term values).

The distribution of the sectors with positive and negative anomalies remains from year to year, though the absolute values and areas of the sectors vary. This variability often exceeds the value of trend changes during 10-15 years. The ratios between values of temperature, precipitation amount and snow-cover thickness are close by the order of values and this allows year-to-year anomalies to be considered as an analogue of a possible snow-cover reaction to the modern and future climatic changes.

Modelling of regional snowpack stratigraphy on the basis of meteorological information makes it possible to obtain stratigraphic columns of snowpack and the data necessary for estimation of typical values of snow-cover water storage. The structure of snowpack is defined by regional (zonal, sectoral) parameters of winter climatic conditions. In regions with temperate continental climate the snow-cover stratigraphy is characterized by a large number of layers and texture heterogeneous elements, while a homogeneous snowpack made up of faceted crystals is common in regions with continental climate.

Relief forms, vegetation type, moisture of soils and ground influence the spatial and temporal variability of snow structures at the local level.

\section{REFERENCES}

Bader, H.P. and P. Weilenmann. 1992. Modeling temperature distribution, energy and mass flow in a (phase-changing) snowpack. I. Model and case studies. Cold Reg. Sci. Technol., 20(2), 157-181. Derksen, C. and E. LeDrew. 2000. Variability and change in terrestrial snow cover: data acquisition and links to the atmosphere. Progr. Phys. Geogr., 24(4), 469-498. 
Dyunin, A.K. 1963. Mekhanika metelei [Mechanics of snowstorms]. Novosibirsk, Akademiia Nauk SSSR. [In Russian.]

Fallot, J.M., R.G. Barry and D. Hoogstrate. 1997. Variations of mean cold season temperature, precipitation and snow depths during the last 100 years in the former Soviet Union (FSU). Hydrol. Sci. J., 42(3), 301-327.

Fierz, C. 1998. Field observation and modelling of weak-layer evolution. Ann. Glaciol., 26, 7-13.

Golubev, V.N. 1987. Nekotoryye zakonomernosti prostranstvennoi neodnorodnosti svoistv i stroeniya snezhnogo pokrova na sklonakh gor [Some regularities of nonuniformity of snow texture properties in space on mountain slopes]. In Trudy 2-ogo Vsesoyuz. soveshchaniya po lavinam, Yangiabad, mai 1985 [Proceedings, 2nd All-Union Symposium on Avalanches, Yangiabad, May 1985]. Leningrad, Gidrometeoizdat, 220-228. [In Russian.]

Golubev, V.N. and E.V. Guseva. 1987. Osobennosti energo i massoperenosa $v$ stratifitsirovannoi snezhnoi tolshche [Features of heat and mass-transfer in the stratified snowpack]. In Voitkovsky, K.F. and M.B. Dyurgerov, eds. Snezhniyy pokrov v gorah i laviny [Snow cover in mountains and avalanches]. Moscow, Nauka, 62-74. [In Russian.]

Golubev, V.N., V.N. Konischchev, S.A. Sokratov and P.B. Grebennikov. 2001. Vliyanie sublimatsii sezonnogo snezhnogo pokrova na formirovanie izotopnogo sostava povtornozhilnych I'dov [Influence of sublimation in a seasonal snow cover on formation of an isotopic content of wedge ice]. Earth Cryo., 3, 71-77. [In Russian.]

Golubev, V.N., M.N. Petrushina and D.M. Frolov. 2006. Vliyanie variacii rezhima vypadeniya osadkov i temperatury na raspredelenie snezhnogo pokrova, ego stroenie i svoistva [The influence of variations of winter conditions of precipitation and temperature on distribution of snow cover, its structure and properties]. In Mezhdunarodnaia konferentsiia; teoriia i praktika otsenki sostoianiia kriosfery Zemli i prognoz ee izmenenii [Proceedings of International Conference on Earth Cryosphere Assessment: Theory, Application and Prognosis of Alterations]. Vol. 1. Tyumen, Tyumen State Oil and Gas University, 202-206. [In Russian.]
Guseva, E.V. and V.N. Golubev. 1989. Thermomechanical mathematical model of the formation of the structure and properties of the snowcover. Geolournal, 19(2), 193-200.

Josberger, E.G. and N.M. Mognard. 2002. A passive microwave snow depth algorithm with a proxy for snow metamorphism. Hydrol. Process., 16(8), 1557-1568.

Kolomyts, E.G. 1976. Struktura snega i landshaftnaya indikatsiya [The snow structure and the landscape indication]. Moscow, Nauka. [In Russian.]

Kominami, Y., Y. Endo, S. Niwano and S. Ushioda. 1998. Viscous compression model for estimating the depth of new snow. Ann. Glaciol., 26, 77-82.

Krenke, A.N., V.N. Razuvaev, L.M. Kitaev, R.A. Martuganov and R.I. Shakirzjanov. 2000. Snezhost' na territorii SNG i ego regionov $v$ usloviyakh global'nogo potepleniya [Snowiness on $\mathrm{CIS}$ area and its regions in the conditions of global warming]. Earth Cryo., 4(8), 97-106. [In Russian.]

Lehning, M., P. Bartelt, B. Brown, T. Russi, U. Stöckli and M. Zimmerli. 1999. SNOWPACK model calculations for avalanche warning based upon a new network of weather and snow stations. Cold Reg. Sci. Technol., 30(1-3), 145-157.

Lokoshenko, M.A. 2005. Snezhnyi pokrov i ego sovremennye izmeneniya $\vee$ Moskve [Snow cover and its current changes in Moscow]. Russ. Meteorol. Hydrol., 6, 71-82. [In Russian.]

Popova, V.V. and A.N. Krenke. 2004. Svyaz' mnogoletnikh kolebanii tolschiny snezhnogo pokrova $v$ Severnoi Evrazii $s$ krupnomasshtabnoi atmosfernoi tsyrkulyatsiei [Relation of longterm variation of snow cover depth in Northern Eurasia with large-scale atmospheric circulation]. Mater. Glyatsiol. Issled., 96, 25-33. [In Russian with English summary.]

Razuvaev, V.N., E.G. Apasova, O.N. Bulygina and R.A. Martuganov. 1995. Variations in the diurnal temperature range in the European region of the former USSR during the cold season. Atmos. Res., 37(1-3), 45-51.

Sturm, M., J. Holmgren and G.E. Liston. 1995. A seasonal snow cover classification scheme for local to global applications. J. Climate, 8(5), 1261-1283. 